\title{
AN ALTERNATIVE DEVELOPMENT STRATEGY FOR COCONUT SMALLHOLDER SECTOR IN SRI LANKA
}

\author{
NIMAL A. FERNANDO and SUMITH de SILVA ${ }^{1}$
}

\begin{abstract}
This paper briefly outlines several important characteristics of the coconut sector in Sri Lanka and provides a theoretical rationale for state intervention in terms of a special smallholder development strategy in the coconut sector. It points out that the current geneml development strategy of the Ministry of Coconut Industries which relies heavily on provision of development subsidies for selected capital development activities is inadequate to deal with the development problems confronted by the sector in geneml and particularly by the resource-poor smallholders. Finally, a two-tier development strategy is proposed for the sector with heavy focus on the smallholders with a poor resource base.
\end{abstract}

\section{INTRODUCTION}

In terms of the extent under cultivation coconut is the most important tree crop in Sri Lanka. The coconut sector accounts for about $20 \%$ of the total cultivated extent in the country. In 1981, the estimated extent under coconut was about 1,035,850 acres, which was more than the combined extent under tea the most irnportant foreign exchange earner in the country and rubber. Significant position of the smallholders has been a salient characteris of the coconut sector. The smallholdings simply defined as holdings below 20 acres in size account for $99 \%$ of the holdings and $75 \%$ of the extent. Holdings below 5 acres in size account for $87 \%$ of the holdings and $46 \%$ of the extent (Coconut Development Authority, 1986). Thus, in Sri Lanka coconut is predominantly a smallholder crop.

Another significant characteristic of the coconut sector is its low level of labour absorption. According to one estimate the total employment in the coconut cultivation sector was around 85,000. (People's Bank, 1981 : 11). Its contribution to both export earnings and household income has also been low. Since coconut is cultivated mainly as a mono-crop and every little inter-cropping is practiced, and the average land productivity remains much below the potential, the pattem of land use in the coconut sector is considered highly inefficient particularly due to the severe scarcity of land resources in the country. Thus, both from a macroeconomic point ofview of utilizing scarce resources more efficiently, increasing foreign exchange eamings and creating productive employment opportunities for a greater number of people and from micro-point of view enhanemg rural household incomes and improving the quality of life of a large number of smaMiolders and their family members, development of the coconut sector deserves greater policy emphasis. Given the predominant position of the smallholders "coconut development in the context of Sri Lanka" means essentially focus on the smallholders, particularly those smallholders who operate land holdings of 5 acres or below in size with a poor resource-base and poor overall access to state assistance schemes operated on a general basis.

\footnotetext{
${ }^{1}$ Deputy Director, Rural Credit Department of the Central Bank of Sri Lanka and former Director Planning, Ministry of Coconut Industries, Sri Lanka, respectively.
} 


\section{THEORETICAL RATIONALE FOR A SPECIAL SMALLHOLDERS DEVELOPMENT STRATEGY}

Cultivation of perennials by smallholders is not a phenomenon confmed only to Sri Lanka. Perennials such as rubber, tea, coffee, cocoa and oil palm are cultivated by millions of smallholders in a large number of countries in Asia, Africa and Latin America. Also most of these cultivations have been developed by them virtually without or with minimal state assistance (Jayasooriya et. al., 1981). In some cases, smallholder development of perennial crops took place in an environment which was clearly hostile to such cultivators.

The conditions which prevailed histoxically have now changed considerably. The smallholders in many developing countries now face higher costs of production and problems of access to new technology - biological, chemical and mechanical - which have been developed during the past two or three decades. At the same time some of them are now faced with replacement problems as the plant stock, which is their main asset, has reached, or is on the verge of the replacement age. Given their current income and consumption expenditure levels, vulnerability to price fluctuations in otitput and input markets, poor access to long-term finance, socio-economic and demographic characteristics of their households and the macro-economic framework within which they are compelled to function it is difficult for them to adopt without extemal assistance (external to the household) measures which raise the output and income levels generated by their smallholdings. Since other sectors of their economies do not in general grow at a reasonably high rate - perhaps with the exception of Malaysia - to offer attractive opportunities for many of these smallholders the best approach to the upliftment of their economic status lies in raising their land and labour productivity and there by the income levels. Given their high relative importance in the rural economy such a strategy would have considerable effects on overall growth and development of these countries.

A major challenge facing governments and development planners in developing countries is to develop strategies which will not only increase output but also reach the millions of small farmers of perennials who remain outside the main-stream of development so that output increases are combined with better regional distribution of income, reduction in poverty and more egalitarian distribution of income earning opportunities in the economy. If development strategies are not focussed on resourcepoor groups of growers while desired output increments may be achieved in some countries, there will be continuing paverty and even more skewed pattem of income distribution (Barlow and Jayasooriya: 1984).

\section{SRI LANKA'S DEVELOPMENT STRATEGY}

In Sri Lanka, Coconut Development Strategy (CDS), as outlined by the Ministry of Coconut Industries (MCI) emphasizes, inter alia, increasing yield per unit of land gradually to a reasonably high level (but still below potential), maintaining the current extent under cultivation more or less at the same level, promoting intercropping among a wide circle of farmers and bringing an increased extent of coconut under irrigation. The CDS also aims at diversification and promotion of coconut-based products and expansion of export markets.

While the broader approach of the CDS appears to be sound the prograrnmes through which this; approach is translated into concrete actions remain somewhat unclear. Therefore, there is an urgent need to discuss the finer details and the issues involved with due consideration to the macro-econornic developments of the country.

From the point of view of the national economy there is a need to increase production in order to meet the rising dernand for domestic consumption and to divert an increasing amount of nuts for the export market mainly in the form of processed kernel products. At the same time there 
is also a need to increase the incomes of the growers. Though increases in supply will have a depreessing effect on prices, the increase in productivity per unit of land may enable the growers to obtain a greater total income.

\section{A TWO-TEER DEVELOPMENT STRATEGY}

The coconut sector is faced with numerous development problems. A multi-pronged approach is required to find solutions to ihese numerous problems faced by the sector. On the one hand attention should be focussed on the declining or stagnant productivity and the wide gap between potential productivity and realized productivity of coconut lands. On the other hand, low level of income and employment per unit of land also need to be tackled by increasing the land use intensity. The improvernent of productivity requires greater adoption of a number of better cultural practices such as regular applications of fertilizer and moisture conservation measures. Also replacement of senile palms with high yielding seedlings is necessary. In order to raise income and employment levels promotion of intercropping and livestock activities are required. Measures which result in increases in yield of coconut will also contribute to better incomes.

Outside the growers' land, there are a number of areas in which policy actions are required. It has been often pointed out that a remunerativeprice to the growers for the nuts is of crucial importance in inducing both short-term afid long-term investments in the coconut cultivation sector (Central Bank of Ceylon, 1980, 1983). While this is true, the problem remains to be seen as to how the govermnent can ensure a remunerative price or retarn to the growers. It is recognized that there appears to be no feasible and efficient direct methods of ensuring adequate prices or returns. However, there are indirect methods by which the Government could assist the growers to obtain better prices and/or returns. The development strategy outlined here is based upon this basic presumption, among others.

Although the coconut sector is characterized by a high degree of heterogeneity which is evident in a number of aspects, within this heterogeneous structure one could identify a resource-poor group of cultivators whose holdings are, say below 5 acres in size. This category has little or no surplus funds to reinvest in coconut development, their households are faced with greater level of unemployment and/or under-employment and they are reluctant to take risks associated with both short-term and long-term reinvestments. They are also less articulate than the rich relatively large landholders, and cannot effectively deal with the existing machinery of state bureaucracy. As a result, they face higher transaction costs in obtaining assistance under the subsidy schernes being operated by the government.

The development needs of the smallholders in the above category are different from those of the others. Growers in this category require better quality seedlings and fertilizer under the subsidy schemes for their replanting and underplanting activities. Provision of these two inputs will enable them to meet bulk of the cash component of the investments necessary for such development work. A cash grant may also be necessary in certain cases to meet the shortfall in their current income during the gestation period of investment and to provide a greater inducement to take risks associated with such investment. They also need easy access to institutional fmance to meet the cost of inputs such as fertilizer and the cost of development of supplementary sources of water say dug wells.

The existing subsidy schemes constitute ad-hoc, unintegrated attempts to resolve the problems of the coconut sector in general (Fernando, 1986). Besides the access problems and high transaction costs to the bulk of the smallholders, the schemes do not provide an incentive to convert the mono-crop coconut holdings into high income generating farms, which is the need of the day, given scarce land resources in the country and considerable poverty and unemployment in the rural sector. Therefore, a different approach to development of the coconut sector which focusses 
emphasis on the resource-poor category of growers is urgently needed to meet the requirements of the sector.

This does not mean however that no emphasis be placed on other growers. Research and improvement of infrastructural facilities will bring benefit to other growers who do not require a "special intensive target oriented programme". All categories will benefit from the export promotion measures and product development activities which will raise the demand for nuts. Expansion of the area under toddy tapping will also have positive effects on the nut prices, benefits of which will accrue partly to growers in this category as well. Thus, what is proposed here is a two-tier strategy which consists of general development activities on the one hand and a special target group oriented programme on the other. A major advantage of this strategy is that it combines growth objective with distribution and, reduction in poverty are expected through improvement of productivity and income levels of the resource-poor in a context where incentives for greater production in larger holdings are not distorted.

The special target group oriented programme should have the following major elements :

a) the target group is defmed as the resource-poor growers whose holdings are less than 5 acres in size. Holdings below $1 / 2$ acre in size should be excluded from the target group because they are mainly home gardens;

b) the objective of the programme is to assist the growers in the target group to convert their mono-crop holdings into intensively cultivated farms generating a greater kvel of output and incorne.

The programme should be implemented in high potential areas on a selective basis. This is required in order to realize economies of scale in providing extension services, inputs such as seedlings and planting materials and providing a number of other ancilliary services which may be necessary for bulk. of the resource-poor farmers. The strategy should focus on supply of high yielding seedlings for planting and supply of fertilizer in time until the plantS reach at least the age of 6 - 7 years. Cultivation of intercropping also requires special emphasis particularly among the replanters, in order to reduce the impact of short-fall in current income due to replanting during the gestation period. Greater emphasis on planting material is particularly necessary due to the long economic life of coconut palms. Plant stock constitutes the major asset in a coconut holding and its quality determines the strearn of future output. Due to the sunk capital embodied in the already established palms, the growers are highly unlikely to replace palms until their productivity declines substantially.

While attempting to increase the productivity of smallholding in the short-term as well as long-term which leads to an upward shift in the supply curve of nuts the strategy should also aim at measures leading to an upward shift in the demand curve for nuts. At present the shift in the demand curve depends mainly on the increase in population. Penetration into new markets and consolidation of the position in the existing markets for kernel products will have a signiflicant demand inducing effect. Development of new kernel-based products will also have a similar effect on the demand curve for nuts. Products which wifl have a greater income elasticity of demand may create an additional demand for nuts as the consumers in the higher income brackets may demand such products.

Another important element of the overall development strategy should be the promotion of non-kernel-based coconut products. The difference between the promotion of kernel-based products and non-kernel-based products lies in that the latter in general does not lead to a direct increase in the demand for nuts, though it leads to an increase in opportunities for earning a greater income from other components of coconut palms. A variety of products fall into this latter category. 
Some of them are, coconut shell charcoal, coconut-based beverages, coconut timber for housing construction purposes and furniture production. There is a potential for developing such products for both domestic as well as export markets. This potential needs to be exploited through a systematic programme which may include pubhc assistance for research and market promotion in some cases. The development strategy should be comprehensive enough and well-integrated to hamess this potential to the benefit of both the growers and the national economy.

Given the resource-position of bulk of the smallholders, and the social context in which they operate the strategy should include a long-terin objective of organizing growers' societies and strengthening their bergaining position viz-a-viz nut dealers and processors. If such societies can be developed under a phased programme as an essential component of the development strategy, a number of benefits may be derived. They may be able to play an important role in supplying inputs, marketing the produce of the members and improving the access to public assistance schemes including extension services. Also from the Government's point of view, the cost of operating assistance schemes may be reduced substantially as economies of scale may be realized through such societies.

\section{SUMMARY AND CONCLUSIONS}

A large number of smallholders in many developing countries have historically cultivated perennials without or with minimal state assistance. These sinallholders, however, face numerous development problems now due to the subsequent developments in their economies and due to poor access to the technological developments which have taken place during the past three decades the current macro and micro-economic and technological situation and institutional structure are such that these growers need extemal assistance to improve their smallholdings.

In Sri Lanka, the coconut sector is predominantly a smallholder sector which consists largely of holdings below 5 acres in size. Most of them are not in a position to convert their monocrop coconut holdings into intensively cultivated farms generating a higher level of output and incomes. The existing general development strategy consisting largely of provision of various type of development subsidies is inadequate for this purpose as it tends to by-pass-most of the needy who are less articulate and politically and economically less influential. Thus, a special comprehensive strategy which focusses on the resource poor is required.

Given the scarce resource position-both fmancial and manpower-of the state such a strategy should be implemented on a selective basis with particular emphasis on supply of quality highyielding seedlings for replacement and supply of fertilizer in time during the immature stage of plants. Intercropping also required special emphasis. Since it is recognized that there appears to be no feasible and efficient direct methods of ensuring adequate nut prices by the state to producers greater emphasis be placed on measures leading to an upward shift in the demand curve for nuts. 


\section{REFERENCES}

Barlow, C, and S.K. Jayasooriya (1984), "Problems of Investment for Technology Advances : The Case of Indonesian Rubber Small Holdings", Journal of Agricultural Economics. Vol. 35, No. 1.

Centml Bank of Ceylon (1980), Review of the Economy, 1979, Colombo, Sri Lanka. (1983), Review of the Economy, 1982 Colombo, Sri Lanka.

Coconut Development Authority (1986), Sri Lanka Coconut Statistics, 1985, Ministry of Coconut Industries, Colombo, Sri Lanka.

Femando, Nimal A. (1986), Public Assistance for Smallholder Tree Crop Development : A Study of the Coconut Smallholder Sector in Sh Lanka, (Mimeo), Coconut Development Authority, Colombo.

Jayasooriya, S.K. et.al., (198 1), "Farmers" Long-term Investment Decisions : A Study of Sri Lankan Rubber Smallholders", The Joumal of Development Studies. Vol. 18 No. 1.

People's Bank (1 98 1), An Economic Study of the Coconut Industry in Sri Lanka, People's Bank, Research Department, Colombo. 